BMJ Paediatrics Open

\section{Supporting marginalised children with school problems in the COVID-19 pandemic}

Ripudaman Singh Minhas (D) , ,2,3 Sloane J Freeman ${ }^{1,2}$
To cite: Minhas RS, Freeman SJ. Supporting marginalised children with school problems in the COVID-19 pandemic. BMJ Paediatrics Open 2021;5:e000956. doi:10.1136/ bmjpo-2020-000956

Received 23 November 2020 Revised 29 December 2020 Accepted 30 December 2020

Check for updates

\section{(c) Author(s) (or their} employer(s)) 2021. Re-use permitted under CC BY-NC. No commercial re-use. See rights and permissions. Published by BMJ.

${ }^{1}$ Department of Pediatrics, Temerty Faculty of Medicine, University of Toronto, Toronto, Ontario, Canada

${ }^{2}$ Department of Pediatrics, St. Michael's Hospital, Li Ka Shing Knowledge Institute, Unity Health Toronto, Toronto, Ontario, Canada

${ }^{3}$ Division of Developmental Pediatrics, Department of Pediatrics, Temerty Faculty of Medicine, University of Toronto, Toronto, Ontario, Canada

Correspondence to Dr Ripudaman Singh Minhas; ripudaman.minhas@unityhealth. to
In March 2020, the WHO's declaration of the COVID-19 global pandemic ${ }^{1}$ resulted in unprecedented public health recommendations to minimise viral spread. This included a major disruption in the cornerstone of children's lives and well-being-school closures.

School boards have since sought to implement a range of novel measures to minimise viral transmission while maintaining access to education. Today, students have the option of learning via virtual learning platforms, in person or through hybridised virtual and in-person models. For the first time in decades, the conventional model of education delivery has undergone rapid change while simultaneously the COVID-19 pandemic has unveiled and exacerbated existing inequities for children with school problems. Consequently, healthcare providers must adapt their response to school-based problems during the pandemic. They must also use lessons learnt to re-invent an approach to address inequities in caring for the $10 \%-15 \%$ of children who will present with these issues at some point in their school years. ${ }^{2}$

Children with learning, behavioural and social-emotional problems require careful assessment of their educational environment and socioeconomic circumstances. The learning ecosystem is informed by teachers and school paraprofessionals, while social risks are determined by careful history taking and screening. Distance learning however presents challenges for educators to characterise educational, behavioural and developmental needs. Additionally, school support staff such as educational assistants, speech and language pathologists, occupational therapists and psychologists may not be able to provide a comprehensive assessment using virtual platforms. Moreover, nearly $15 \%$ of children in the USA lack reliable access to broadband internet and many do not have a dedicated device to connect to school. ${ }^{3}$ While children with socioeconomic disadvantage are at greater risk of learning and behavioural challenges and developmental disabilities, they face more barriers to distance learning and support. This conundrum will impact school attendance and performance and must be considered when assessing school challenges. ${ }^{4}$

The physical classroom may reveal features that suggest disorders such as learning disabilities, attention-deficit/hyperactivity disorder (ADHD) and autism spectrum disorder (ASD), which can be overlooked in a virtual setting. For students attending virtual classes, the experience may be socially isolating, rather than a communal journey including: preparing for group projects, participating in team sports and recreation and interacting during unstructured lunch and recess times. The virtual school experience itself may negatively impact learning and behaviour which may not be recognised or readily monitored by educators or clinicians. Furthermore, for some children, learning at home may be stressful due to increased concerns for domestic violence, child maltreatment and parental mental health disorders exacerbated by the pandemic. Similarly, the learning losses associated with school closures have a greater impact for low-income students who have reduced access to supplementary educational materials and tutoring and are less likely to have parental supervision or support of learning at home. These factors must be taken into account when assessing learning needs. ${ }^{5}$

Virtual schooling also presents challenges in assessing the impact of both pharmacologic and non-pharmacologic behaviour interventions. Without direct observations and interactions, teachers have fewer occasions to observe changes in behaviours such as attention and focus, which help guide clinicians in the treatment of ADHD. Likewise, the behavioural impacts of social skills programmes and selfregulation curricula may be difficult to assess without direct peer interactions. Additionally, 
clinicians' recommendations for accommodations and modifications to the curriculum and learning environment are more difficult to implement through virtual means.

Measures taken to limit viral transmission in the classroom, including mask wearing and physical distancing, impact learning, behaviour and social development. Since masks interfere with speech recognition, students with hearing and language impairment or new language learners may have difficulties understanding speech and instruction. Masks can obscure facial affect and non-verbal communication, further complicating children's perceptions of social interactions. Physical distancing may cause anxiety for young children learning to socialise. Further, students isolating from peers because of social challenges may be misunderstood as trying to conform to new social norms such as physical distancing. This misperception could result in teachers not recognising a student's social struggles and underreporting these challenges on standardised diagnostic questionnaires. For neurodevelopmental disorders that require time-sensitive therapeutic interventions, delayed or missed diagnoses could be detrimental. This phenomenon could also impact the reported prevalence and epidemiological patterns of these disorders.

It has also become more difficult to monitor children with known developmental disorders that impact socialisation, such as ASD, social anxiety or selective mutism, in the classroom setting. Worsening social difficulties may be attributed to a 'regression' in skills, rather than the struggle to navigate a dynamic, unfamiliar social landscape. Like many DSM5 (Diagnostic and Statistical Manual of Mental Disorders, 5th Edition)diagnoses, specialists must consider whether reported social challenges are causing functional impairments by comparing to accepted social norms, which are themselves shifting and nebulous for the neurotypical population.

The barriers associated with virtual learning and today's in-person classroom environment present challenges in obtaining and integrating educational history and observations into a plan. Increasing economic instability and parental unemployment may also contribute to academic and behavioural challenges whether studying online or in person. During the pandemic, paediatricians may not have enough input from educators and must rely more heavily on caregivers to provide behavioural and educational observations of children learning at home. This may not be feasible for caregivers who are essential workers or are overburdened with economic strain or family responsibilities. Clinicians also need to consider the impact of learning losses attributed to school closures and distance learning on a child's presentation, especially for marginalised students with barriers to accessing school online and encountering socioeconomic instability. When using standardised diagnostic tools to assess behaviour and development, practitioners must also consider the dynamics of the learning environment and psychosocial context. Further, there is a need for increased vigilance for learning, behaviour and developmental problems that may be subclinical or insidious in this current educational climate, particularly for those with social risk factors. Paediatricians would benefit from more frequent follow-up and assessment with students who have a history of learning and behaviour challenges especially for students experiencing social inequities, after they have settled into their learning programme.

The COVID-19 pandemic has resulted in drastic changes to the environments in which children learn and play and has revealed vast disparities in access to virtual education, developmental resources and support. Paediatricians should use this opportunity to redefine a model of care to support at-risk children with school problems as diagnosticians, counsellors, advocates and liaisons with their educational teams. In response to these widespread changes, traditional approaches to the assessment and management of school problems must adapt to meet the evolving needs of marginalised children impacted by the pandemic and beyond.

Contributors RSM and SJF conceptualised, drafted, reviewed and revised the manuscript for submission. All authors approved the final manuscript as submitted and agree to be accountable for all aspects of the work.

Funding The authors have not declared a specific grant for this research from any funding agency in the public, commercial or not-for-profit sectors.

Competing interests SJF discloses grants and personal fees received from Lysol, Canada, outside the scope of this work.

Patient and public involvement Patients and/or the public were not involved in the design, or conduct, or reporting, or dissemination plans of this research.

Patient consent for publication Not required.

Provenance and peer review Not commissioned; externally peer reviewed.

Open access This is an open access article distributed in accordance with the Creative Commons Attribution Non Commercial (CC BY-NC 4.0) license, which permits others to distribute, remix, adapt, build upon this work non-commercially, and license their derivative works on different terms, provided the original work is properly cited, appropriate credit is given, any changes made indicated, and the use is non-commercial. See: http://creativecommons.org/licenses/by-nc/4.0/.

ORCID iD

Ripudaman Singh Minhas http://orcid.org/0000-0002-0291-9585

\section{REFERENCES}

1 World Health Organization. WHO Director-General's opening remarks at the media briefing on COVID-19 - 11 March 2020. Available: https://www.who.int/dg/speeches/detail/who-director-general-sopening-remarks-at-the-media-briefing-on-covid-19-11-march-2020 [Accessed 18 Oct 2020].

2 Andrews D, Mahoney W. Children with School Problems: A Physician's Manual. 2nd edn. Mississauga, ON: John Wiley \& Sons, Canada, 2012

3 Fishbane L, Tomer A. As classes move online during COVID-19, what are disconnected students to do? Brookings Scholar, 2020. Available: https:// www.brookings.edu/blog/the-avenue/2020/03/20/as-classes-moveonline-during-covid-19 -what-are-disconnected-students-to-do/

4 Minhas RS. How COVID-19 is widening disparity in children's developmental potential. The Toronto Star, 2020. Available: https:// www.thestar.com/opinion/contributors/2020/10/27/how-covid-19is-widening-disparity-in-childrens-developmental-potential.html [Accessed 15 Dec 2020].

5 Hanushek EA, Woessmann L. The economic impacts of learning losses. OECD, 2020. Available: http://www.oecd.org/education/ The-economic-impacts-of-coronavirus-covid-19-learning-losses.pdf [Accessed 20 Oct 2020]. 